\title{
RANCANGAN MODEL PEMBELAJAR BLENDED LEARNING PADA PROGRAM PENDIDIKAN BAHASA INGGRIS DI UNIVERSITAS TIMOR INDONESIA
}

\author{
Oleh: Febronia Lasi ${ }^{1}$, Hery Yanto The $^{2}$ \\ (Dosen Universitas Timor, Nusa Tenggara Timur) ${ }^{1}$ \\ Email: febry1202@gmail.com \\ (Dosen Zhejiang Yuexiu University of Foreign Languages, China) ${ }^{2}$ \\ Email: herythe@qq.com
}

\begin{abstract}
Abstrak
Tulisan ini menyajikan rancangan konseptual pengembangan pembelajaran blended learning mata kuliah Percakapan dan Mendengarkan Bahasa Inggris untuk mahasiswa Program Studi Pendidikan Bahasa Inggris di Universitas Timor (Unimor). Blended learning dianggap sebagai model pembelajaran yang tepat untuk diterapkan di Unimor karena dalam pelaksanaannya memungkinkan adanya perpaduan antara pertemuan tatap muka di kelas dengan komponenkomponen pembelajaran daring. Penggunaan berbagai teknologi daring juga diidentifikasi dengan memperhatikan kebutuhan pemelajar untuk mengembangkan keterampilan sesuai keahlian di bidangnya. Pelaksanaan blended learning dapat mendukung mahasiswa untuk memperoleh kualitas hasil belajar yang lebih baik. Kajian konseptual mengenai pengembangan mata kuliah blended learning ini dimulai dengan memaparkan prinsip-prinsip blended learning yang dapat diterapkan di Unimor, kemudian dilanjutkan dengan identifikasi manfaat pelaksanaannya pada mata kuliah Bahasa Inggris. Rancangan konseptual pada tulisan ini selanjutnya akan digunakan sebagai landasan teori untuk mendukung penelitian pengembangan mata kuliah blended learning Percakapan dan Mendengarkan Bahasa Inggris di Unimor.
\end{abstract}

Kata Kunci: Blended Learning, Desain Pembelajaran, Bahasa Inggris

\section{THE DESIGN OF THE SPEAKING AND LISTENING BLENDED LEARNING COURSE IN THE ENGLISH LANGUAGE DEPARTMENT OF TIMOR UNIVERSITY}

\begin{abstract}
This paper is a theoretical framework used to design and develop the blended learning course of Comprehensive Speaking and Listening for the students of the English Language Department in the University of Timor (Unimor). The blended learning is considered the proper learning approach to the learning in Unimor due to the possibility of it to enable the integration of face-to-face class-meeting with the online learning. The use of various online technologies is also being taken into account considering the needs of learners to develop skills related to their field of study. The blended learning implementation in Unimor means to
\end{abstract}


support the students to have quality learning experiences. First, this conceptual paper explains principles of blended learning models that can be applied to the learning process of Unimor's students. Following that there is an analysis of the benefits of the implementation of blended learning in teaching and learning English. Further the theoretical framework will be used as the literature review of the developmental study to be conducted in developing the blended learning course Comprehensive Speaking and Listening for the students of Unimor

Keywords:Blended Learning, Learning Design, English Language Learning

\section{A. PENDAhuluan}

Sebagian dosen di Universitas Timor Indonesia (Unimor) masih banyak yang menerapkan proses belajar mengajar dengan ceramah. Mahasiswa umumnya datang ke kelas untuk mendengarkan penjelasan dosen dan mereka membuat catatan. Dosen umumnya menggunakan handout, spidol dan papan tulis untuk menyampaikan konsep dan ide pembelajaran yang dianggap penting untuk diketahui oleh mahasiswa. Mahasiswa sesekali diminta untuk menjawab pertanyaan yang diajukan dalam bentuk kuis. Tidak jarang mahasiswa juga diberi soal-soal latihan. Pada akhir semester, mahasiswa diberi ujian tertulis.

Pendekatan belajar yang terlalu didominasi dengan kegiatan berpusat pada pengajar (teacher center approach) telah teridentifikasi kurang sesuai untuk meningkatkan kualitas belajar karena pada umumnya pembelajaran tersebut menekankan pada pentingnya menghafal konsep supaya dapat dituangkan kembali dalam kertas jawaban ujian (Schon, 1983). Pembelajaran seperti ini tidak mendukung mahasiswa untuk mengembangkan kemampuan berpikir kritis, tidak memacu mahasiswa untuk memikirkan penyelesaian masalah, tidak mengasah kemampuan melakukan penafsiran dan pengendalian perkembangan keterampilan diri, serta tidak membuat mahasiswa terbiasa mengemukakan pendapat dan melakukan pengambilan keputusan (Barrows, 1992). Pendekatan belajar mengajar berpusat pada pengajar memang dapat menuntun perkembangan kemampuan mahasiswa untuk mengetahui konsep, namun tidak memberikan banyak kesempatan kepada mereka untuk mengembangkan kemandirian dalam belajar (Trilling \& Fadel, 2009). Pemelajar memang dipandu dan dibimbing untuk meniru model yang diberikan oleh pengajar sehingga dapat menyelesaikan tugas yang 
diberikan dan lulus test, namun mereka tidak memperoleh latihan keterampilan untuk mengantisipasi kondisi nyata ketika harus bekerja di di lingkungan kerja pada tingkat global (Kompa, 2012).

Berbeda dengan pendekatan belajar mengajar berpusat pada pengajar, pembelajaran berpusat pada pemelajar (student centered learning approach) memberi porsi lebih besar pada kegiatan mahasiswa. Kegiatan belajar mengajar dirancang sesuai dengan kebutuhan, minat, aspirasi dan latar belakang budaya, serta keunikan pemelajar. Mahasiswa diberi motivasi untuk menunjukkan keterampilan yang dimiliki dan dituntut untuk mengemukakan ide-ide kreatif. Mahasiswa diberi peluang untuk menyampaikan saran kepada pengajar mengenai hal-hal yang ingin dipelajari dan mereka dapat berperan aktif untuk menghasilkan produk hasil belajar atau ide-ide baru. Pembelajaran dapat berlangsung di kelas, tempat magang, masyarakat, komunitas virtual di internet, dan berbagai tempat belajar yang memungkinkan mereka mendapatkan informasi untuk belajar dan mengembangkan keterampilan diri. Mengacu pada Standar Pembelajaran ISTE tahun 2017, pembelajaran berpusat pada pemelajar berhasil jika kreativitas dan efektivitas penggunaan teknologi untuk mendukung proses belajar memenuhi kebutuhan belajar mereka. Teknologi merupakan perangkat penting hanya jika perangkat tersebut dapat digunakan untuk memberdayakan perkembangan pedagogi pemelajar dan membantu pemelajar mengembangkan keterampilan untuk dapat berpartisipasi aktif sebagai warga masyarakat di masa depan (ISTE, 2017).

Dengan adanya teknologi digital dan akses internet, belajar dan pelatihan keterampilan dapat dilakukan di luar kelas. Lingkungan belajar tersebut dapat berupa, namun tidak terbatas pada museum, taman, lingkungan belajar di laman internet, pusat pelatihan, tempat latihan kebugaran, dan studio-studio kesenian (Bleed, 2001). Pemanfaatan lingkungan belajar ini akan memberi kesempatan kepada pemelajar untuk mendapatkan hasil belajar yang langsung dapat diterapkan di bidang keahliannya. Tersedianya panggilan video juga turut mempermudah pengajar mengundang pakar dan informan untuk memberikan informasi dan inspirasi belajar tanpa harus dibatasi oleh perbedaan tempat dan waktu. Panggilan 
video dan lingkungan belajar daring telah semakin banyak digunakan oleh berbagai institusi pendidikan dan pelatihan untuk melaksanakan pembelajaran daring dan pembelajaran jarak jauh. Kondisi ini juga dapat dimanfaatkan oleh Unimor untuk meningkatkan kualitas belajar mahasiswa, namun tentu saja transformasi ini tidak dapat dilakukan dengan terburu-buru karena mahasiswa dan pengajar telah terbiasa dengan pembelajaran berpusat pada pengajar. Sebagai jalan tengah untuk mempermudah transformasi tersebut, penulis melihat potensi memadukan kebiasaan yang telah ada dan memasukkan unsur baru secara perlahan ke dalam proses perkuliahan. Unsur baru tersebut mencakup peralihan kegiatan di kelas dari berpusat pada pengajar menuju peningkatan aktivitas mahasiswa untuk berpartisipasi, dan pertemuan kelas dipadukan dengan fasilitasi belajar menggunakan berbagai media daring. Kombinasi antar-pendekatan ini sudah cukup dikenal dengan sebutan blended learning.

Blended learning pada tulisan ini dapat dipahami sebagai kombinasi kegiatan instruksional secara tatap muka di dalam kelas dengan penyampaian materi secara daring menggunakan berbagai teknologi yang tersedia dan dapat diakses melalui lingkungan belajar berbasis internet (Williams, 2002). Teknologi yang tersedia dapat berupa video-video pembelajaran, forum diskusi, jaringan sosial, aplikasi penyimpanan data berbasis daring, aplikasi desain, dan permainan edukasi daring yang bersifat kolaboratif. Ada bebagai model dan rancangan blended learning (Horn \& Staker, 2014), seperti integrasi teknologi berbasis daring ke dalam kegiatan instruksional di kelas, penyampaian materi belajar melalui pertemuan kelas yang dipadukan dengan kegiatan belajar mandiri di sistem manajemen belajar (learning management system) berbasis daring, atau menggunakan telekonferensi dan pertemuan tatap muka di kelas secara terpadu, pemberian nilai tambahan kepada pemelajar untuk pertemuan kelas jika mereka melakukan aktivitas belajar daring, dan masih banyak lagi bentuk yang lain. Blended learning telah berkembang sangat pesat di tingkat pendidikan tinggi saat ini dan banyak institusi pendidikan telah memperoleh manfaat dari menerapkannya (Arabasz, Boggs, \& Baker, 2003). Dengan semakin lancarnya akses internet di kampus dan tersedianya berbagai jenis gawai yang dapat 
digunakan untuk mengakses internet, blended learning menjadi lebih mudah untuk diterapkan di Unimor.

Sebelum merencanakan penelitian ini, penulis telah melakukan uji coba pelaksanaan blended learning untuk kuliah Pengembangan Kurikulum dan Pembelajaran di Unimor. Pembelajaran dilakukan dengan memadukan pertemuan tatap muka dengan telekonferensi menggunakan WIZIQ (perangkat daring untuk video konferensi), rekaman video instruksional, dan manajemen sistem belajar Edmodo. Sebagian besar mahasiswa pada program uji coba teridentifikasi sangat termotivasi untuk mencoba berbagai perangkat daring yang digunakan di luar kelas dan berusaha menyelesaikan tugas yang ada pada Edmodo di warung internet. Kendala utama yang dihadapi dalam pelaksanaan adalah tidak tersedianya akses internet yang memadai di kampus sehingga telekonferensi sering terputus.

Berlandaskan pada uji coba ini, penulis kemudian mengembangkan rancangan konsep penelitian ini. Ada dua pertanyaan yang coba dijawab pada rancangan konseptual ini. Pertama, prinsip-prinsip blended learning seperti apa saja yang perlu mendasari pengembangan mata kuliah Percakapan dan Mendengarkan Bahasa Inggris? Kedua, apa saja manfaat pelaksanaan blended learning dari penelitian sebelumnya yang juga dapat diperoleh oleh mahasiswa dan pengajar Unimor? Kajian konseptual pada tulisan ini pada tahap selanjutnya akan digunakan oleh peneliti untuk melaksanakan penelitian pengembangan mata kuliah tersebut.

\section{Prinsip-prinsip Blended Learning}

Blended learning merupakan program pendidikan yang diterapkan di dalam sistem pendidikan formal dan pemelajar menjalani proses belajar mengajar dengan memadukan pertemuan kelas dengan pertemuan belajar secara daring (Horn \& Staker, 2014). Lebih lanjut, Horn dan Staker (2014) juga menekankan bahwa di dalam proses belajar berbentuk blended learning, pemelajar diberi kesempatan untuk mengontrol proses belajar secara mandiri dan pengawasan serta bimbingan oleh pengajar dilakukan untuk memastikan pemelajar mendapatkan 
pengalaman belajar sesuai dengan yang ditetapkan dalam tujuan belajar. Pemelajar blended learning memperoleh pengalaman belajar melalui partisipasi secara aktif dalam kegiatan belajar, berinteraksi dengan pemelajar lain, memperoleh mentoring serta panduan dari pengajar, serta menggunakan berbagai sumber belajar untuk menyelesaikan tugas-tugas belajar (Garrison \& Kanuka, 2004).

Dalam pelaksanaannya, blended learning tidak hanya menambahkan komponen daring dan teknologi ke dalam proses belajar mengajar, namun mencakup proses transformasi belajar dan perancangan ulang mata kuliah. Untuk melakukan transformasi mata kuliah tatap muka di kelas ke bentuk blended learning, pengajar harus merancang ulang mata kuliah yang diajarkan dengan cara mengidentifikasi kombinasi yang tepat antara kegiatan instruksional di lingkungan belajar fisik (kelas) dengan pembelajar di lingkungan daring, dan memastikan rancangan kegiatan belajar dapat membantu pemelajar memperoleh pengalaman belajar yang berarti dan berkualitas (Bleed, 2001). Pemelajar tidak hanya sekedar diberikan perangkat-perangkat dan teknologi daring untuk belajar (Dziuban, Hartman, \& Moskal, 2004). Peranan pengajar sangat penting sebagai pemandu dan pengawas kegiatan belajar. Pengajar harus memastikan perangkat dan teknologi daring yang dipilih dan digunakan oleh pemelajar dapat membantu mereka untuk meningkatkan kemampuan memperoleh informasi dan keterampilan belajar baik dengan menjalankan aktivitas belajar di kelas maupun di lingkungan belajar daring (Dziuban, Hartman, \& Moskal, 2004). Dalam model pembelajaran blended learning, teknologi tidak digunakan hanya untuk menggantikan aktivitas di kelas. Teknologi berfungsi membantu dan mendukung pelaksanaan aktivitas belajar, baik di kelas maupun di luar kelas.

Mata kuliah dengan model blended learning yang berkualitas adalah kombinasi belajar daring dan tatap muka di kelas yang mendukung pemelajar mencapai keberhasilan belajar, meningkatkan efektivitas administrasi, dan dilandasi strategi serta metode belajar mengajar yang berkualitas (Keengwe \& Agamba, 2015). Dalam kegiatan belajar, terjadi pergeseran dari pembelajaran berpusat pada pengajar ke pembelajaran berpusat pada pemelajar (Senffner \& 
Kepler, 2015). Keterlibatan pemelajar di dalam aktivitas belajar mencakup membaca, menulis, berbicara berpikir, berdebat, melakukan kerja kelompok, dan melakukan peragaan hasil kegiatan belajar (Dodge, Whitmer, \& Frazee, 2015). Jika diterapkan dengan tepat, blended learning akan memberikan manfaat yang sangat besar kepada pembelajar, pengajar, dan pelaksanaan administrasi institusi penyelengara pendidikan (Vaughan, 2007). Manfaat-manfaat tersebut dapat berupa meningkatnya kualitas tugas yang diselesaikan, berkurangnya jumlah waktu yang diperlukan untuk menyelesaikan tugas tersebut, meningkatnya partisipasi dan peran aktif pemelajar dalam melaksanakan tugas belajar, dan dalam jangka panjang akan meningkatkan reputasi institusi (Vaughan, 2007).

\section{B. METODE PENELITIAN}

\section{Rancangan Pelaksanaan Blended Learning}

Ditegaskan oleh Senffner \& Kepler (2015), Keengwe \& Agamba (2015), dan Dodge, Whitmer, \& Frazee (2015), pelaksanaan pembelajaran blended learning merupakan hasil dari pertimbangan seksama perancangan pembelajaran untuk memberikan pengalaman belajar terbaik baik pemelajar. Blended learning jelas merupakan hasil dari suatu proses panjang perancangan kegiatan instruksional. Untuk menghasilkan blended learning yang berkualitas baik, salah satu model perancangan kegiatan instruksional yang dapat digunakan adalah model ADDIE yang dipopulerkan oleh Dick dan Carey (1990). Model ini akan digunakan sebagai landasan untuk mengembangkan blended learning di Unimor. Pada bagian ini akan dibahas secara ringkas lima tahap di dalam perancangkan kegiatan instruksional model ADDIE, yaitu analysis, design, development, implementation, dan evaluation.

Pada tahap analisis, perancang kegiatan belajar mengajar harus melakukan kerjasama dengan berbagai pihak yang terlibat di dalam pelaksanaan kegiatan pencapaian tujuan belajar untuk mengumpulkan informasi mengenai pemelajar, institusi pembelajaran, dan materi-materi belajar. Informasi mengenai pemelajar yang perlu dikumpulkan mencakup data demografis, latar belakang budaya, kondisi psikologis, dan latar belakang individu. Pada tahap ini perancang kegiatan 
instruksional harus memiliki kepekaan yang tinggi dalam mengidentifikasi sumber-sumber dan fasilitas-fasilitas belajar yang dapat digunakan untuk mengembangkan rancangan pembelajaran. Sumber-umber dan fasilitas-fasilitas belajar tersebut bisa saja berasal dari sekitar lingkungan kampus dan bisa pula dari lingkungan di luar kampus. Meskipun perancang pembelajar juga bisa saja adalah pengajar mata kuliah yang telah bertahun-tahun mengampu mata kuliah yang sama, namun pengajar harus menyadari bahwa transformasi kegiatan belajar dari pertemuan kelas ke model blended learning merupakan suatu proses dan kegiatan perancangan yang baru. Hal yang paling penting adalah perancang mata kuliah harus mengidentifikasi manfaat-manfaat dan pengalaman-pengalaman belajar yang dapat diperoleh oleh pemelajar dengan adanya tambahan unsur daring ke dalam perkuliahan. Komponen daring tersebut harus dipetakan dengan jelas dengan tujuan-tujuan belajar yang akan dicapai. Secara ringkas dapat ditegaskan kegiatan analisis bertujuan menentukan kondisi ideal yang perancang instruksional berharap dapat bermanfaat bagi pemelajar dalam mencapai tujuan belajar.

Pada tahap perancangan (design), perancang instruksional menetapkan tujuan-tujuan pembelajaran. Tujuan-tujuan pembelajaran memberikan kejelasan mengenai keterampilan dan pengetahuan yang dapat dikuasai oleh pemelajar setelah menempuh kegiatan belajar. Selanjutnya, perancang instruksional juga menetapkan keluaran yang diharapkan dan indikator untuk mengukur kemampuan pemelajar dalam proses belajar untuk menghasilkan keluaran tersebut. Di tingkat pendidikan tinggi, secara praktis kegiatan ini merupakan bagian dari perancangan silabus, rencana pembelajaran, instrumen evaluasi dan penilaian, serta dokumendokumen pendukung kegiatan belajar lainnya. Dokumen panduan dan aturanaturan pengembangan instrumen pendukung kegiatan belajar tersebut juga perlu dibuat sebelumnya. Jika blended learning merupakan inisiatif dari institusi di tempat pengajar bertugas, lembaga administrasi perguruan tinggi perlu menyiapkan dokumen panduan dan aturan tersebut. Jika pengajar melakukan inisiatif sendiri untuk melakukan perancangan blended learning, maka pengajar dapat mencari panduan pelaksanaan yang tersedia dari institusi lain dan 
melakukan penyesuaian panduan tersebut untuk memenuhi kebutuhan institusi di tempat bertugas.

Tahap ketiga adalah pengembangan (development) strategi instruksional dan merencanakan sumber dan media pendukung kegiatan instruksional. Pengajar menentukan strategi dan media, baik untuk kegiatan tatap muka di kelas maupun kegiatan belajar daring, kemudia menyejajarkan media tersebut satu sama lain untuk saling mendukung dalam satu kesatuan mata kuliah. Pemilihan strategi dan media disesuaikan dengan tujuan pembelajaran yang telah ditetapkan pada tahap kedua. Media dan sumber belajar yang tersedia dan mudah diakses harus diutamakan. Jika diperlukan untuk menambah atau membeli media dan sumber baru, maka perlu juga dipertimbangkan alokasi dana dan sumber daya alternatif jika dana tersebut tidak tersedia.

Ketika rancangan selesai disusun, maka tahap selanjutnya adalah pelaksanaan (implementation) kegiatan instruksional. Pada tahap ini pengajar dan pemelajar mulai melaksanakan proses belajar mengajar. Jika tersedia dana dan waktu yang cukup, maka pelaksanaan dapat diujicobakan terdahulu pada kelompok kecil, namun bisa juga pelaksanaan pada tahun pertama dijadikan sebagai uji coba. Tindakan ini menjadi semakin umum dilakukan oleh institusi pendidikan di masa sekarang. Bahkan tidak jarang peneliti juga menggunakan kuasi-eksperimen untuk mengevaluasi uji coba desain instruksional pada kelas-kelas atau mata kuliah yang diajarnya. Dengan berpegangan pada prinsip pembelajaran berkualitas, kegiatan uji coba ini tetap dapat memenuhi unsur etika pelaksanaan penelitian dan pembelajaran.

Tahap terakhir di dalam model ADDIE adalah evaluasi (evaluation). Tahap ini dilakukan untuk menilai keberhasilan dan kekurangan pelaksanaan kegiatan instruksional dan rancangan yang telah ditetapkan. Menggunakan data yang dikumpulkan dari pelaksaanaan, pengajar mengukur tingkat keberhasilan belajar mahasiswa dan kemampuan desain pembelajaran dalam memenuhi kebutuhan mahasiswa. Evaluasi terutama dilakukan terhadap pembelajaran mahasiswa selama proses dan sesudah proses instruksional. Evaluasi juga dapat dilengkapi dengan pengumpulan pendapat dari mahasiswa mengenai dosen dan mata kuliah. 
Rancangan Model Pembelajaran....(Febronia Lasil dan Hery Yanto The)

Pengajar juga dapat melakukan evaluasi diri terhadap kegiatan yang telah dilakukan dan institusi dapat melakukan evaluasi terhadap pengajar dan kegiatan instruksi dengan melakukan observasi kegiatan instruksional. Menggunakan data hasil evaluasi, pengajar/perancang instruksional dapat membuat rencana-rencana penyempurnaan kegiatan instruksional. Tahapan-tahapan ADDIE dapat diulang kembali.

\section{HASIL PENELITIAN DAN PEMBAHASAN}

\section{Blended Learning Mata Kuliah Bahasa Inggris}

Model pembelajaran blended learning telah banyak dilaksanakan pada berbagai bidang pendidikan di perguruan tinggi. Pelaksanaannya juga menunjukkan hasil yang sangat positif terhadap meningkatnya kualitas pengajaran, motivasi belajar mahasiswa, dan adiministrasi institusi pendidikan (Abdillah, 2006; Paturusi, Chisaki \& Usagawa, 2012; Pratama, 2015; Sulisworo, Rahayu, \& Akhsan, 2016; Mutaqin, Marethi \& Syamsuri, 2016). Pada bagian ini, penulis akan membahas tiga contoh keberhasilan pelaksanaannya di dalam pembelajaran Bahasa Inggris sebagai bahasa asing (English as a Foreign Language/EFL).

Radosavlevikj (2008) mengumpulkan data dari 50 mahasiswa berbagai jurusan yang mengambil mata kuliah EFL dengan model blended learning di South East European University. Komponen daring dari mata kuliah ini dikembangkan menggunakan manajemen sistem belajar universitas bernama LIBRI. Penelitian ini menganalisis data menggunakan pendekatan kuantitatif dan kualitatif. Kesimpulan dari penelitian ini adalah pelaksanaan blended learning memberikan kesempatan kepada mahasiswa untuk melakukan refleksi diri terhadap proses belajar, meningkatkan kemandirian dalam belajar, dan mengembangkan kemampuan manajemen diri. Komponen daring memungkinkan mahasiswa melakukan lebih banyak interaksi dengan pengajar dan mahasiswa lain yang mengambil mata kuiah yang sama. Sistem manajemen belajar memungkinkan pengajar mengumpulkan data mengenai aktivitas belajar daring mahasiswa yang selanjutnya dapat digunakan untuk melakukan evaluasi terhadap 
proses belajar. Mahasiswa menggunakan media daring untuk berdiskusi, memberikan ide, mengemukakan pendapat, dan menyelesaikan tugas kelompok. Hasil kerja mahasiswa yang tersimpan pada manajemen sistem belajar menunjukkan peningkatan kemampuan berpikir kritis.

Peneliti lain, Jiang dan Li (2001) melakukan studi berkelanjutan selama tiga tahun berturut-turut untuk mengidentifikasi sikap dan kemampuan pengajar dan pemelajar pada kelas komprehensif Bahasa Inggris. Kedua peneliti tersebut mengumpulkan data dengan melakukan survei terhadap pengajar dan mahasiswa di Shenyang Aerospace University. Pada bagian kesimpulan studi ini, Jiang dan Li (2001) menegaskan baik pengajar maupun pemelajar yakin bahwa blended learning dapat meningkatkan kemampuan belajar Bahasa Inggris. Selain belajar Bahasa Inggris, pemelajar dan pengajar juga mempelajari berbagai teknologi baru dan memperoleh manfaat dari penggunaan teknologi tersebut untuk mempermudah pencapaian hasil belajar, tidak hanya pada Bahasa Inggris tetapi juga pada bidang lainnya. Baik pengajar maupun mahasiswa menganggap penting kegiatan pelatihan penggunaan teknologi pada manajemen sistem belajar Blended Learning sebelum mereka menggunakannya untuk melaksanakan kegiatan instruksional.

Zumor, Refaai, Eddin, \& Al-Rahman (2013) melakukan penelitian terhadap 160 mahasiswa EFL pada King Khalid University. Penelitian ini dilaksanakan dengan menggunakan pendekatan kuantitatif. Kueisioner yang terdiri atas 33 pertanyaan digunakan untuk mengumpulkan data dari mahasiswa. Berdasarkan data yang dikumpulkan dan dianalisis, peneliti-peneliti tersebut menyatakan lingkungan pembelajaran daring telah meningkakan kuaitas belajar dan memotivasi mereka untuk membaca dan menemukan jawaban terhadap persoalan belajar. Dengan membaca dan mencari informasi sendiri, mereka yakin bahwa telah menguasai lebih banyak kosa kata baru. Beradasarkan pengamatan terhadap aktivitas belajar mahasiswa, para peneliti menemukan lingkungan pembelajaran dan strategi belajar meningkatkan kemampuan mahasiswa dalam bekerja sama, meningkatkan rasa percaya diri dalam mengemukakan pendapat, dan membantu mahasiswa merencanakan dan mengatur jadwal belajar serta penyelesaian tugas. 
Penelitian-penelitian yang telah diringkas tersebut dilakukan pada tiga lokasi yang berbeda yaitu Eropa, Tiongkok, dan Arab Saudi. Meskipun dilakukan pada populasi dengan karakteristik geografis, budaya, dan sistem pendidikan yang berbeda, blended learning menunjukkan hasil yang sama yaitu berpengaruh positif terhadap keberhasilan proses belajar mengajar di perguruan tinggi. Kesimpulan dari ketiga penelitian ini memberikan penegasan bahwa model pembelajaran yang sama dan manfaat yang sama akan dapat diperoleh Unimor jika diterapkan dengan rancangan yang tepat. Model-model pembelajaran yang diterapkan pada studi-studi tersebut dapat dijadikan landasan untuk pengembangan blended learning di Unimor. Tentu saja modifikasi dan perubahan dapat dilakukan untuk menyesuaikan degan kebutuhan mahasiswa.

\section{SIMPULAN}

Blended learning merupakan model pembelajaran yang tepat untuk diintegrasikan pada perkuliahan di Unimor. Model pembelajaran ini memungkinkan adanya perpaduan antara pertemuan tatap muka di kelas dengan komponen pembelajaran daring. Pembelajaran daring dapat didukung dengan berbagai teknologi daring yang diidentifikasi sesuai dengan kebutuhan pemelajar untuk mengembangkan keterampilan sesuai keahlian di bidangnya, seperti telekonferensi, video, dan manajemen sistem belajar. Pelaksanaan blended learning dapat mendukung mahasiswa Unimor memperoleh kualitas hasil belajar yang lebih baik dan meningkatkan efektivitas penyampian instruksional. Kajian konseptual mengenai pengembangan mata kuliah blended learning ini telah memaparkan prinsip-prinsip blended learning yang dapat diterapkan di Unimor, kemudian dilanjutkan dengan identifikasi manfaat pelaksanaannya pada mata kuliah Bahasa Inggris. Rancangan konseptual pada tulisan ini selanjutnya dapat dikembangkan lebih lanjut dan digunakan sebagai landasan teori untuk mendukung penelitian pengembangan mata kuliah blended learning Percakapan dan Mendengarkan Bahasa Inggris di Unimor. 


\section{DAFTAR PUSTAKA}

Abdillah, L.A. (2006). Exploring Student's Blended Learning Through Social Media. ComTech Vol. 7, No. 4, 245-254.

Arabasz, P., Boggs, R., \& Barker, M. B. (2003). Highlights of E-Learning Support Practices, Educause Center for Applied Research Bulletin, 1-11.

Barrows, H. S. (1992). The Tutorial Process. Second Edition. Springfiedl, IL: Southern Illinois School of Medicine.

Bleed. (2001). A Hybrid Campus for a New Millennium. Educause Review 36 (1), $16-24$

Dick, W., \& Cary, L. (1990). The Systematic Design of Instruction. $3^{\mathrm{Rd}}$ edition. Harper Collins.

Dodge, B., Whitmer, J., \& Frazee, J. P. (2015). Improving Undergraduate Student Achievement in Large Blended Courses Through Data-Driven Interventions. In Proceedings of the Fifth International Conference on Learning Analytics and Knowledge - LAK '15 (412-413). New York, New York, USA: ACM Press.

Dziuban, C., Hartman, J., \& Moskal, P. (2004). Blended learning, Educause Center for Applied Research Bulletin, 2004(7), 1-12.

Garrison, D.R., and Kanuka, H. (2004). Blended Learning: Uncovering Its Transformative Potential in Higher Education. The Internet and Higher education, 7(2), 95-105.

Horn, M. B., \& Staker, H. (2014). Blended: Using Disruptive Innovation to Improve Schools. San Francisco: Jossey-Bass.

International Society for Technology in Education. (2017). ISTE Standards for Students: A Practical Guide for Learning with Technology.

Jiang, S., \& Li, D. (2012). An Empirical Study of Blended Teaching Model in University English Teaching. Creative Education. Vol. 3, No.4, 503-506.

Keengwe, J., \& Agamba, J. J. (2015). Models for Improving and Optimizing Online and Blended Learning in Higher Education.

Kompa. (2012). Disadvantages of Teacher-Centered Learning. Diakses pada 17 Agustus 2017 darihttp://joanakompa.com

Mutaqin, A., Marethi, I., \& Syamsuri. (2016). Model Blended Learning di Program Studi Pendidikan Matematika Untirta. Cakrawala Pendidikan, XXXV No. 1, 134-141.

Paturusi, S.D.E., Chisaki, Y., \& Usagawa, T. (2012). Development and Evaluation of The Blended Learning Course at Sam Ratulangi University in Indonesia. International Journal of E-education, e-business, e-management, and e-learning, 2(3), 242-246. 
Pratama, E.Y. (2015). The Implementation of Blended Learning Method Using Edmodo (A social networking site) in Teaching Reading Comprehension (A Mixed-method Study at a University in West Java). International Conference on Language, Literature, Culture and Education 17 th \& $18^{\text {th }}$ OCTOBER, 2015, 181-194.

Radosavlevikj, N. (2008). Implementing Blended Learning in an EFL Classroom. 1st Albania International Conference on Education (AICE), pp. 568-579.

Senffner, D., \& Kepler, L. G. (2015). Blended Learning That Works. Alexandria, VA: ATD Press.

Schon, D.A. (1983). The Reflective Practitioner, How Professionals Think In Action. Basic Books

Sulisworo, O., Rahayu, T., \& Akhsan, R.N. (2016). The Students' Academic Writing Skills After Implementing Blended Learning Using Facebook. Information technology and learning tools, 5(6), 176-191

Trilling, B., \& Fadel, C. (2009). $21^{\text {st }}$ Century Skills, Learning For Life In Our Times. Jossey-Bass Inc Pub.

Vaughan, N. (2007). Perspectives on Blended Learning In Higher Education. International Journal on E-Learning, 6(1), 81-94.

Williams, C. (2002). Learning On-line: a Review of Recent Literature in a Rapidly Expanding Field. Journal of Further Higher Education, 26(3), 263272.

Zumor, A.W.Q.A, Refaai, I.K.A., Eddin, E.A.B., \& Al-Rahman, F.H.A. (2013). EFL Students' Perceptions of a Blended Learning Environment: Advantages, Limitations and Suggestions for Improvement. English Language Teaching, 6(10), 95-110. 